Dept. of Mycoplasma,

Animal Health Research Institute, Dokki

\title{
BACTERIOLOGICAL STUDIES ON MASTITIS OF DAIRY ANIMALS WITH SPECIAL REFERENCE TO MYCOPLASMA INFECTION IN MENOFIA AND KALUOBIA GOVERNORATES, EGYPT
}

(With 4 Tables and 7 Figures)

By

FADIA ABDELHAMEED and EMAN M. SHARAF*

* Dept. of Bacteriology, Animal Health Research Insitiute, Shebin-El-Koom

(Received at 11/3/2009)

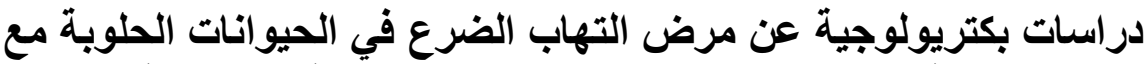

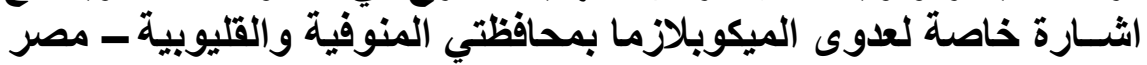

\section{فادية عبل الحمبل ، ابيان شرف}

كان الغرض من اجر اء البحث معرفة مدى انتشار مرض التهاب الضرع الظاهري والخفي في بعض مزارع الابقار الفريزيان و الجاموس الحلوبة (ذات الاعداد المحدودة) بمحافظتي المنوفية و القليوبية لموسم حليب و احد (نوفمبر 2007 الى نهاية ديسمبر 2008 ) و وكذلك معرفة أهم الهم

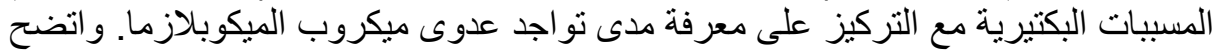

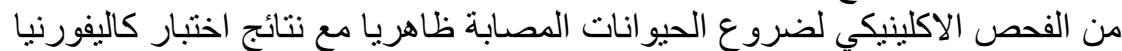

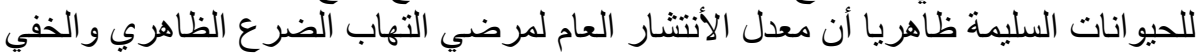

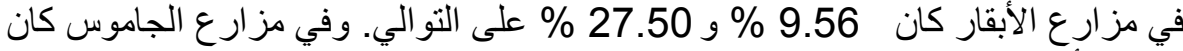

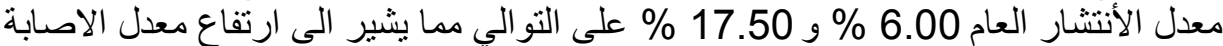

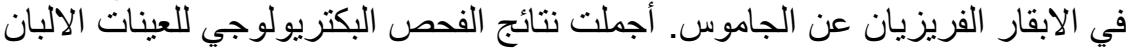

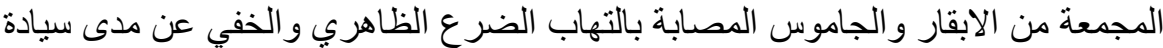

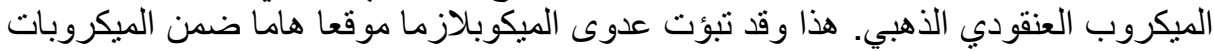

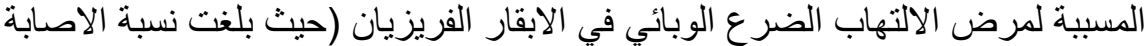

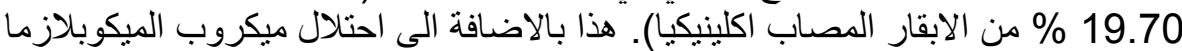

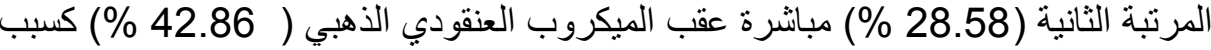

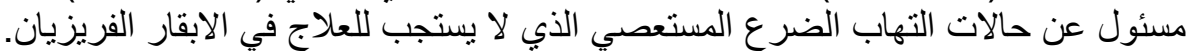

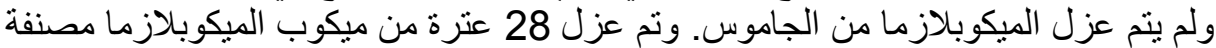

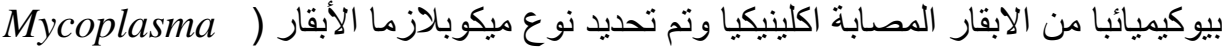

(bovis

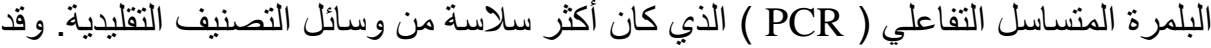

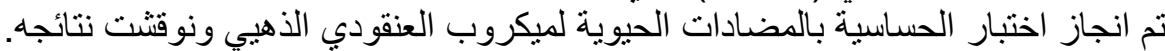

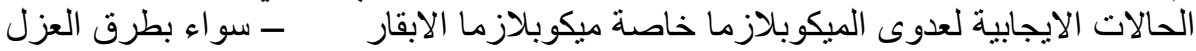

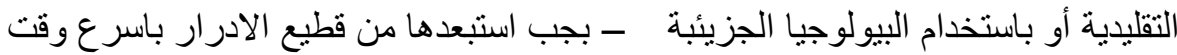




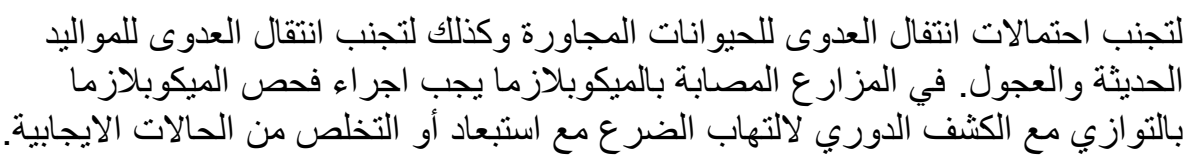

\section{SUMMARY}

Nine small-scale dairy farms include 982 animals (Friesian cows, 565 and buffaloes, 417) at Kaluobia and Menofia Governorates were clinically inspected for detection of udder and/or milk abnormalities, and the apparently healthy animals were subclinically tested by California mastitis test to indicate the prevalence of clinical and subclinical mastitis during one lactation season; Nov., 2007 - Dec., 2008). The isolated bacterial pathogens were identified by conventional culturing procedures whereas the isolated Mycoplasma was molecularly identified using Polymerase Chain Reaction (PCR). The current results indicated that overall prevalence of clinical and subclinical mastitis in cows' farms was $9.56 \%$ and $27.61 \%$, respectively, and in buffaloes' farms was $6.00 \%$ and $17.50 \%$, respectively. The high susceptible rate $(P<0.01)$ of cows to mastitis than buffaloes was discussed. Staphylococcus aureus was the predominant mastitis pathogen of clinical and subclinical mastitis in dairy cows and buffaloes. Mycoplasma could not be isolated from buffaloes. In Friesian cows, Mycoplasma occupied a considerable level of the isolated contagious mastitis pathogen from the clinically mastitic cases $(19.70 \%)$ and it occupied the second grade $(28.57 \%)$ following Staphylococcus aureus $(42.86 \%)$ as etiologic agent responsible for incurable mastitis of cows. Twenty-eight isolates of Mycoplasma were biochemically determined and 17 of them were identified as Mycoplasma bovis by PCR, which is easier and more flexible tool than conventional culturing procedures. In-vitro antibiotic-disc-susceptibility to Staphylococcus aureus was achieved. The culturally and/or molecularly (PCR) positive cases of Mycoplasma mastitis, in particular Mycoplasma bovis mastitis, should culled as early out the dairy herd to avoid the lateral transmissions of infection to neighboring unaffected animals, and to avoid the transmission of infection to neonates and calves. Mycoplasmal examination, in the infected farm, should regularly do in paralleling with routine detection of mastitis until elimination by segregate/cull the infected cases.

Key words: Subclinical, clinical \& incurable mastitis in cows \& buffaloes, bacteria, Mycoplasma, PCR.

INTRODUCTION 
Mastitis is continuously implicated as one of the serious tribulations of the dairy cows and buffaloes inducing severe economic losses during the lactation season. These losses are primarily due to lower milk yield, reduced milk quality, and higher costs of treatment and control (Palanivel et al., 2008 and Nicholas et al., 2009). Microorganisms causing mastitis of dairy animals are numerous, but mastitis pathogens of dairy ruminants can be categorized as environmental (Escherichia coli and other Coliforms) or contagious (Mycoplasma species; streptococcus agalactiae and Staphylococcus aureus) depending on their primary reservoir (environment versus infected mammary gland) (Edmonson and Bramely, 2004 and Reddy et al., 2007). Mastitis caused by contagious pathogens appears to be more prevalence than the environmental mastitis (Riekerink et al., 2006 and Zaitoun, 2008).

On the other side, Mycoplasma mastitis is incriminated as a major enemy facing the dairy industry (Nicholas et al., 2009). Contagious mastitis caused by Mycoplasma of dairy cows and buffaloes is a worldwide disease (Riekerink et al., 2006 and Nicholas et al., 2008) and firstly reported in Egypt by El-Ebeedy et al. (1985) and Zaitoun (1990), respectively. The later authors emphasized that Mycoplasma mastitis coming Egypt through importation of infected Friesian cows. During the past 20 years, several reports on various forms of Mycoplasma mastitis in dairy cows and buffaloes on farms and in individual (private) cases at different localities of Delta-region and of Upper Egypt's Governorates were subsequently published (Eissa, 1986; Ahmed and Sabry, 1989; Zaitoun, 1990; Zaitoun et al., 1991; ElShabiny, and Abou-El-Makarem, 1994). This may obviously refers to the spread of Mycoplasma infection throughout the Egyptian farms and it may become inherent or endemic in some areas. Various types of Mycoplasmas were isolated from dairy Friesian cows and buffaloes with mastitis. These Mycoplasmas included Mycoplasma bovis, Mycoplasma bovigenitalium and Mycoplasma arginini. Mycoplasma bovis appears to be the most important etiologic agent of Mycoplasma mastitis (Nicholas et al., 2008).

From practical point of view, diagnosis of mastitis depends chiefly on the clinical inspection of the grossly affected mammary quarter (s) and thereafter treated by an available antibiotic drug without detection of mastitis pathogen, which consider the cornerstone in mastitis' treatment and control (Zaitoun, 2008). In general, the selected anti-mastitis drug was usually chosen based on the experience of 
veterinarians and/or owners. These may attribute to inadequate facilities of the bacteriological examinations in territories, and not all owners accept the bacteriological analyses of the milk of the affected animals to minimize the costs of diagnosis and they irrationally treated the clinically affected cases haphazardly. This may assist in a build-up of bacterial resistance. Therefore, the current work was carried out to elucidate the following items: a) the prevalence rate of mastitis in cows and buffaloes in some private farms at Menoufia and Kalioubia Governorates. b) to indicate the most common mastitis pathogen(s) responsible for intramammary infections of dairy cows and buffaloes. c) to evaluate the situation of Mycoplasma mastitis, particularly Mycoplasma bovis, among dairy animals population. Antibiotic sensitivity test of the predominant mastitis pathogen(s) was also aimed.

\section{MATERIALS and METHODS}

\section{Animals:}

During the period of investigation (Nov., 2007 to Dec., 2008), a total number of 982 dairy animals were randomly selected and clinically monitored to clear-up any udder and/or milk abnormalities. The apparently healthy cases of the selected animals were subclinically examined using indirect test (California Matitis Test, CMT) (Table 1). The clinically positive cases with signs of udder and/or milk abnormalities were serially enrolled and their therapeutic trials were recorded. Mastitic cases received two consecutive therapeutic trials with adequate therapy without successful results were encountered in our work as incurable mastitis. A composite sample from the clinically affected quarter(s) per each case was collected in screw-capped bottle and sent to the laboratory with minimal of delay, and subjected to bacteriological and mycoplasmal examinations. On the other hand, the subclinically positive quarter(s) of each case were sampled and subjected to the same examinations of the clinically positive samples. To minimize the costs of laboratory examinations, a composite sample from each clinically and/or subclinically positive case was collected and examined.

\section{Samples and Culturing procedures:}

\section{I - Bacteriological examinations:}

The affected quarter was washed, disinfected, and the first strips were rejected. Approximately $25 \mathrm{ml}$ of intramammary secretion was collected in sterile screw-capped bottle. The collected sample was thoroughly vortexed and divided into two halves. The first half was prepared for bacteriological examinations. The sample aerobically 
incubated overnight at $37^{\circ} \mathrm{C}$, and thereafter centrifuged and the sediment was streaked onto $10 \%$ sheep's blood agar (Gibco) and onto MacConkey agar (Oxoid) plates. The cultured plates were aerobically incubated to $24-48$ hours at $37^{\circ} \mathrm{C}$. The suspected colonies were picked-up, purified, morphologically identified and biochemically analyzed according to the criteria illustrated by Watts (1990).

\section{II- Mycoplasmal examinations:}

The second half of each collected sample was thoroughly mixed in vortex and $0.2 \mathrm{ml}$ was drawn and poured into screw capped bijou bottles containing $1.8 \mathrm{ml}$ of modified Hayflick's broth medium supplemented with inhibitors, fresh yeast extract and horse serum, and incubated at $37^{\circ} \mathrm{C}$ (Stalheim, 1990). The incubated bottle was thereafter platted onto agar media and incubated in $5 \% \mathrm{Co}_{2}$ environment. Twodays post incubation, the cultured plates were examined and agar-blocks of the positive plate with characteristic shape of Mycoplasma colonies were taken and recultured, purified and subjected to digitonin sensitivity test (Stalheim, 1990). The digtonin sensitive strains were identified biochemically viz., glucose fermentation, arginine hydrolysis and film and spots tests (Table 2). The glucose negatve, arginine negative Mycoplasma with production of film and spot was selected to molecular testing using polymerase chain reaction (PCR).

\section{PCR procedure:}

Twelve purified strains of the frozen isolated Mycoplasmas were selected based on the biochemical profile [glucose fermentation (-ve), arginine hydrolysis (-ve) and film and spot (+ve)] and thawed, cultured into PPLO broth medium, incubated for $48 \mathrm{hrs}$ at $37^{\circ} \mathrm{C}$. The incubated cultured broths were tested by a Mycoplasma bovis-specific PCR according to the protocol illustrated by Lunini et al. (2006) and Radaelli et al. (2008). Briefly, five milliliters of the cultured broth was harvested for $30 \mathrm{~min}$ at $14000 \mathrm{xg}$ and the pellet was primarily washed with Mycoplasma wash solution to remove all adhering medium-additives from the Mycoplasma-cell (Rodwell and Whitecomb, 1983). Thereafter the pellet was resuspended in $300 \mu 1$ of distilled water treated with $0.1 \%$ of diethylpyrocarbonate and the DNA was extracted from $100 \mu \mathrm{l}$ using the DNeasy Tissue Kit (QIAamp ${ }^{\circledR}$ DNA Mini, Qiagen $\left.{ }^{\circledR}\right)$. Specific primers were designed for PCR (MYCBV-Fw - 5'-TAT CGG TGA CCC TTT TGC AC-3'; MYCBV-Rw - 5'-TTC CAC TTC CTG ACT CAC CA-3'). A PCR with these primers resulted in the production of a fragment of $348 \mathrm{bp}$ of the oppD (oligopeptide permease D) gene of Mycoplasma bovis. A final volume of $20 \mu \mathrm{l}$ was used containing $0.2 \mu \mathrm{M}$ 
of each primer, $200 \mu \mathrm{M}$ of dNTPs, 2 units of Taq polymerase (Roche Diagnostics), $1 \times 1.5 \mathrm{mM}$ of $\mathrm{MgCl}_{2}$ and $5 \mu \mathrm{l}$ of the extracted DNA. The following amplification procedure was used: $95^{\circ} \mathrm{C}$ for $5^{\prime}, 36$ cycles at $95^{\circ} \mathrm{C}$ for $1^{\prime} 59^{\circ} \mathrm{C}$ for $30^{\prime \prime}$ and $72^{\circ} \mathrm{C}$ for $30^{\prime \prime}$ and 72 for $7^{\prime}$. Ten microliters of the amplified product were analyzed by electrophoresis in a $1.8 \%$ agarose gel (Agarose, MP, Multi purpose agarose, Boehringer Manheim). Unfortunately, a reference strain of Mycoplasma bovis could not be obtained in our hand and consequently PCR products were sequenced with an automatic capillary system (Applied-Biosystem) to confirm the specificity of the reaction.

On the other hand, specific primers of Mycoplasma bovigenitalium (Mbg-Fw - 5'-CGT AGA TGC CGC ATG GCA TTT ACG G-3'; Mbg-Rw - 5'-CAT TCA ATA TAG TGG CAT TTC CTA C-3') was also incorporated in molecular detection of Mycoplasma bovigenitalium of the examined milk according to protocol illustrated by Kobayashi et al. (1998).

\section{Antibiotic sensitivity test:}

Ten isolates of the isolated Staphylococcus aureus strains were randomly selected and in-vitro tested to different members of antibiotics commonly used in field; penicillin (10 IU), ampicillin (10 $\mu \mathrm{g})$ cloxacilline $(5 \mu \mathrm{g})$, cephalothin $(30 \mu \mathrm{g})$, oxytetracycline $(30 \mu \mathrm{g})$, and enrofloxacin $(5 \mu \mathrm{g})$. The technical procedure and interpretation of the applied test were carried out as described by Ortez (2005).

\section{Statistical analyses:}

The obtained data of clinical and subclinical mastitis of the examined dairy cows and buffaloes collected, pooled and statistically analyzed. The prevalence of mastitis calculated mathematically by conventional procedure. The significance difference of the prevalence of clinical and subclinical mastitis of the examined cows and buffaloes was carried out using CHI square analysis according to the outlines illustrated by Lewis (1966).

\section{RESULTS}

\section{Prevalence of clinical and subclinical mastitis:}

Prevalence (\% affected) of clinical and subclinical mastitis of the examined dairy cows and buffaloes in different farms was tabulated on Table 1, and the overall prevalence was mathematically calculated (Table 1). On the other hand, the prevalence rate of incurable cases of mastitis in both species was listed on Table 1 . 
Statistically, CHI-square analysis revealed that there is a significance increase $(\mathrm{P}<0.05)$ in the susceptibility rate of Friesian cows to clinical mastitis $(9.56 \%)$ than buffaloes $(6.00 \%)$. Concerning the subclinical mastitis, Friesian cows are highly susceptible $(\mathrm{P}<0.01)$ to the subclinical form of mastitis $(27.61 \%)$ than buffaloes $(17.50 \%)$. There is no significance difference $(\mathrm{P}>0.05)$ in the prevalence rate of incurable mastitis in the examined cows $(3.72 \%)$ and buffaloes (2.64\%).

\section{Mastitis pathogens:}

The isolated bacterial pathogens including Mycoplasma infections of the bacteriologically examined samples of dairy cows and buffaloes were illustrated on Table 2. The Table indicated that Staphylococcus aureus followed by Streptococcus agalactiae was the predominant isolates and Mycoplasma infections occupies the third grade of the isolated pathogen. On the other hand, the microbial pathogens isolated from the incurable mastitis cases of cows and buffaloes were summarized on Table 3, which indicates that Staphylococcus aureus and Mycoplasma infections were the predominant etiologic agents responsible for incurability of intramammary infection.

The Mycoplasmal examinations indicated that 13 (cases of the examined cows with signs of clinical mastitis, $\mathrm{n}=59$ ) harbored Mycoplasma either alone $(14.81 \%)$ or coupled with Staphylococcus aureus $(9.26 \%)$ in their mammary sections and 28 isolates were determined. Of these isolates, 20 strains were digitonin sensitive and encountered as Mycoplasma strains. The biochemical profiles of the isolated Mollicutes were illustrated on Table 4.

\section{PCR Procedure:}

All biochemically glucose negative, arginine negative with positive production of film and spot $(\mathrm{n}=20)$ were molecularly tested by PCR. All PCR-tested isolates were negative to Mycoplasma bovigenitalium and 17 isolates gave the specific product of Mycoplasma bovis (Fig. 4). Unfortunately, 3 strains could not be identified.

\section{Frequent distribution of the isolated mastitis pathogens:}

The frequent distribution of the isolated bacterial mastitis pathogens and Mycoplasma of the examined dairy cows and buffaloes with clinical and subclinical mastitis were diagrammed in Figures 2, 3, 4, and 5. The microbial pathogens and Mycoplasma isolated from the incurable mastitis cases were figured on Fig. 6 and 7.

\section{Antibiotic sensitivity test:}


Seventy percentage of the tested of Staphylococcus aureus strains $(n=10)$ were sensitive to penicillin and other antibiotics. Meanwhile the reminder were varies in their resistance. Two strains were penicillin resistant but they were sensitive to ampicillin, cloxacilline, cephalothin, oxytetracycline, and enrofloxacin. One strain was resistant to penicillin and oxytetracycline. All tested isolates was highly sensitive to enrofloxacin.

Fig. 1: Eithidium bromide-stained, $1.8 \%$ agarose electrophoresis of PCR product of the tested Mycoplasma isolates

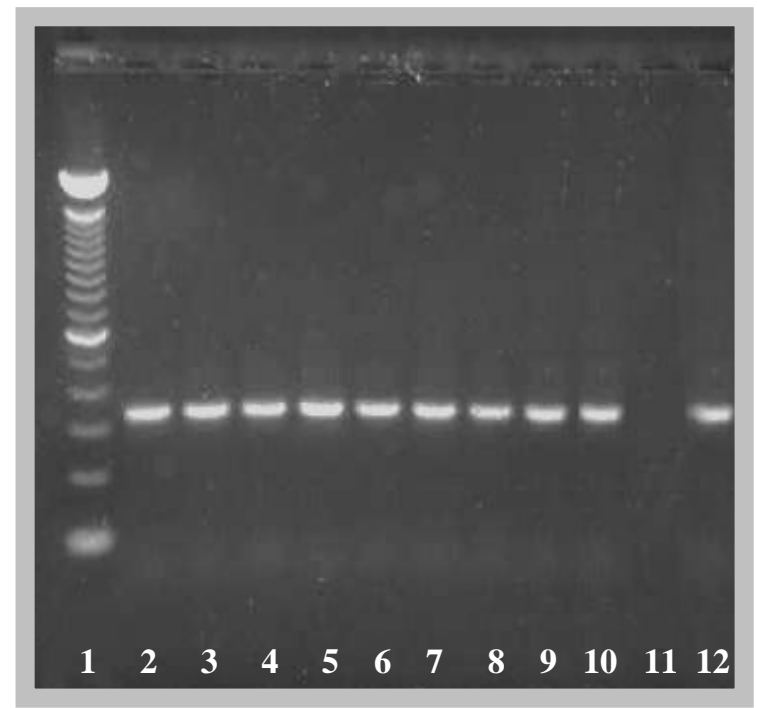

- 1: DNA ladder, $100 \mathrm{bp}$

- Arrow: The arrow refers to the specific band of Mycoplasma bovis, $348 \mathrm{bp}$.

- 2-10: Field isolates of Mycoplasma bovis (Glucose negative, arginine negative, Film \& spots positive)

- 11: Arginine positive Glucose negative Mycoplasma (may be Mycoplasma arginini)

- 12: Field isolated strain of Mycoplasma bovis 
Fig. 2: Frequant distribution (\%) of the mastitis pathogens( $n=66$ isolates) isolated from clinical mastitis cases $(n=54)$ of the examined dairy cows $(n=$ $565)$

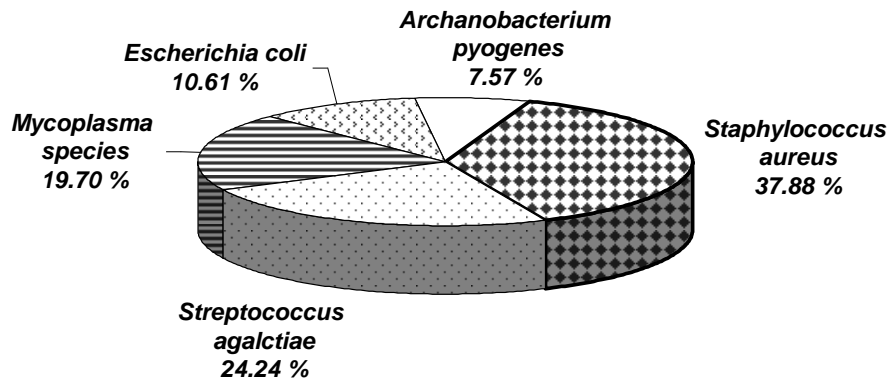

Fig. 3: Frequent distribution $(\%)$ of the mastitis pathogens $(n=194)$ isolated from subclinical mastitis cases $(n=156)$ of the examined dairy cows $(n=565)$

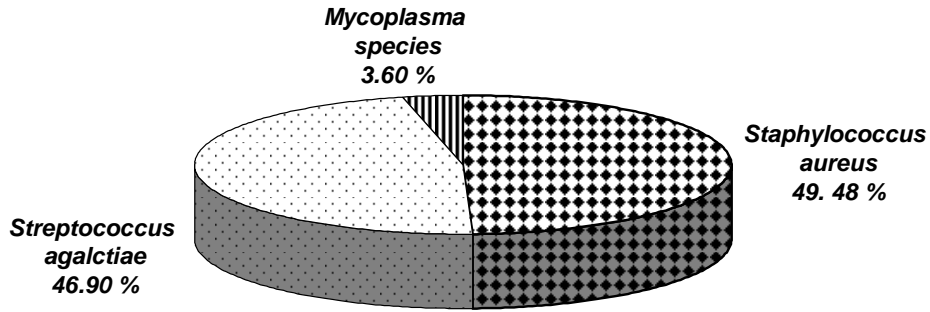


Fig. 4: Frequent distribution (\%) of the mastitis pathogen isolated from clinical mastitis cases $(n=25)$ of the examined dairy buffloes $(n=417)$

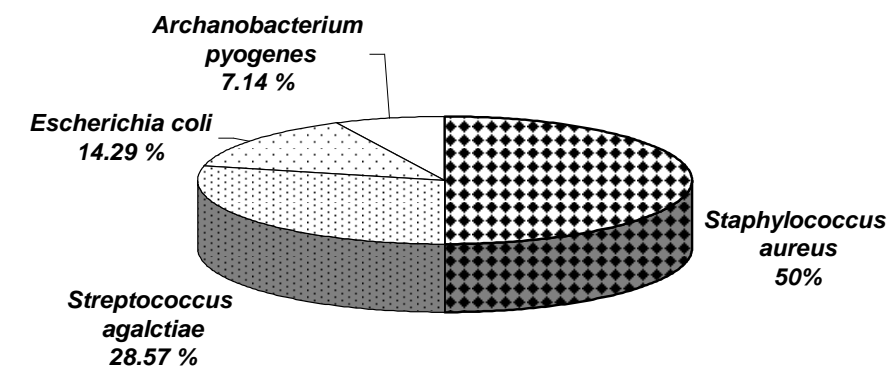

Fig. 5: Frequent distribution (\%) of the isolated mastitis pathogen $(n=81)$ isolated fron subclinical mastitis cases $(n=73)$ of the examined fairy buffaloes ( $n=417)$

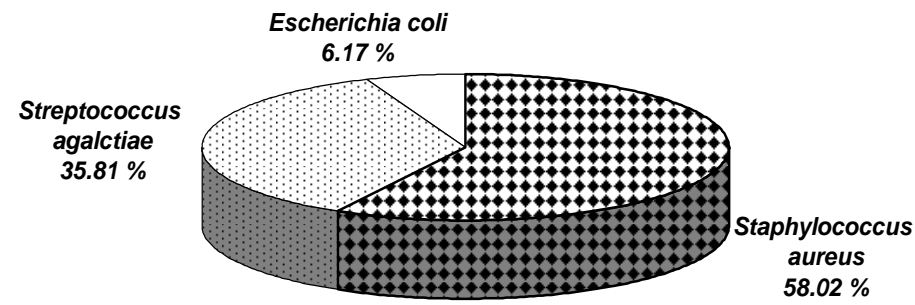


Fig. 6: Frequent distribution (\%) of mastitis pathogens isolated from incurable mastitis of dairy cows ( $n=21$ cases)

Escherichia coli

$10.71 \%$

Archanobacterium pyogenes

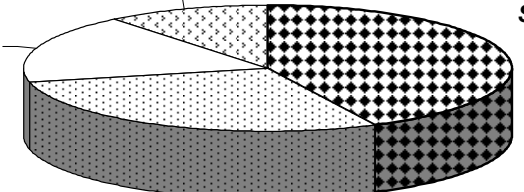

Staphylococcus

aureus

$17.86 \%$

Mycoplasma

species

$28.57 \%$

Fig. 7: Frequent distribution (\%) of mastitis pathogens isolated from incurable mastitis of dairy buffloes ( $n=11$ cases)

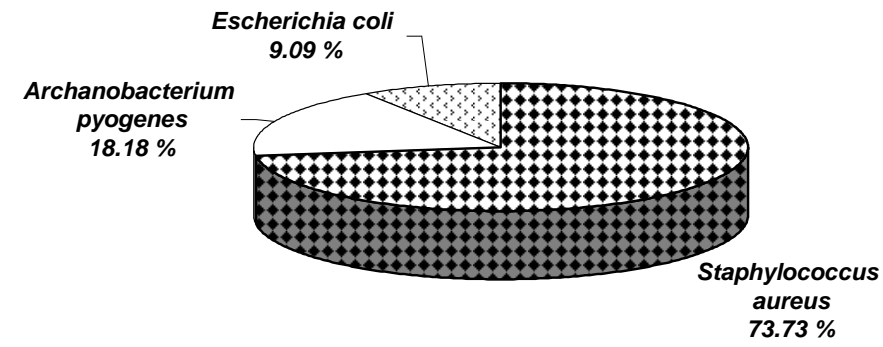


Table 1: Prevalence of clinical and subclinical mastitis of the examined dairy cows $(n=565)$ and buffaloes $(n=417)$ in small private farm during one lactation season

\begin{tabular}{|c|c|c|c|c|c|c|c|}
\hline \multirow[t]{2}{*}{ Governorate } & \multirow{2}{*}{$\begin{array}{l}\text { Farms/Number of } \\
\text { animals }\end{array}$} & \multicolumn{3}{|c|}{ Cows } & \multicolumn{3}{|c|}{ Buffaloes } \\
\hline & & Clinical & Subclinical & $\begin{array}{l}\text { Incurable } \\
\text { cases }^{\#}\end{array}$ & Clinical & Subclinical & Incurable cases \\
\hline \multirow{5}{*}{ Kaluobia } & A/ 85 & -- & -- & -- & $5(5.88 \%)$ & $14(16.47 \%)$ & $2(2.35 \%)$ \\
\hline & B / 109 & $10(9.17 \%)^{\$}$ & $32(29.38 \%)$ & $4(3.67 \%)$ & -- & -- & -- \\
\hline & C/ 93 & $11(11.83 \%)$ & $25(26.88 \%)$ & $4(4.30 \%)$ & -- & -- & -- \\
\hline & $\mathrm{D} / 119$ & $10(8.40 \%)$ & $34(28.57 \%)$ & $3(2.52 \%)$ & -- & -- & -- \\
\hline & E/ 79 & $7(8.86 \%)$ & $22(27.85 \%)$ & $2(2.53 \%)$ & -- & -- & -- \\
\hline \multirow{4}{*}{ Menofia } & F/ 165 & $16(9.69 \%)$ & $43(26.06 \%)$ & $8(4.48 \%)$ & -- & -- & -- \\
\hline & $\mathrm{G} / 122$ & -- & -- & -- & $8(6.55 \%)$ & $21(17.21 \%)$ & $4(3.28 \%)$ \\
\hline & $\mathrm{H} / 175$ & -- & -- & -- & $9(5.14 \%)$ & $28(20.44 \%)$ & $5(2.86 \%)$ \\
\hline & I / 35 & -- & -- & -- & $3(8.57 \%)$ & $10(28.57 \%)$ & -- \\
\hline \multirow{2}{*}{$\begin{array}{l}\text { Total } \\
\text { examined } \\
\text { animals }\end{array}$} & Cows $(n=565)$ & $54(9.56 \%)^{*}$ & $156(27.61 \%)^{* * *}$ & $21(3.72 \%)^{@}$ & -- & -- & -- \\
\hline & Buffaloes $(n=417)$ & -- & -- & -- & $25(5.99 \%)$ & $73(17.50 \%)$ & $11(2.64 \%)^{@}$ \\
\hline
\end{tabular}

\#: Incurable mastitis is cases did not response to two consecutive therapeutic trials with one and/or two types of anti-mastitis udder infusions.

$\$$ : Number between parentheses is the percentage of infection.

*: Significance increase at the 0.05 level $\left(\chi^{2}=4.11, P<0.05\right)$.

**: Highly significance increase at the 0.01 level $\left(\chi^{2}=12.834, P<0.01\right)$.

@: There is no significance difference in the rate of incurable mastitis in both examined cows and buffaloes $\left(\chi^{2}=0.520, P>0.05\right)$.

N.B: the prevalence (\% affected) of mastitis (clinical plus subclinical form) of dairy cows is therefore $37.17 \%$ and of dairy buffaloes is $23.50 \%$. The incurable mastitis cases were not encountered as clinical form of mastitis in the present work. 
Table 2: Microbial isolates* from clinical and subclinical mastitis of dairy cow and buffaloes:

\begin{tabular}{|c|c|c|c|c|}
\hline \multirow[t]{2}{*}{ Isolated microorganisms } & \multicolumn{2}{|c|}{ Clinical Mastitis } & \multicolumn{2}{|c|}{ Subclinical Mastitis } \\
\hline & $\begin{array}{l}\text { Cows } \\
(\mathrm{n}=54)\end{array}$ & $\begin{array}{c}\text { Buffaloes } \\
(\mathrm{n}=25)\end{array}$ & $\begin{array}{c}\text { Cows } \\
(\mathrm{n}=156)\end{array}$ & $\begin{array}{c}\text { Buffaloes } \\
(\mathrm{n}=73)\end{array}$ \\
\hline Staphylococcus aureus & $\begin{array}{c}13 \\
(24.07 \%)^{\#}\end{array}$ & $\begin{array}{c}11 \\
(44.00 \%)\end{array}$ & $\begin{array}{c}58 \\
(37.18 \%)\end{array}$ & $\begin{array}{c}39 \\
(53.42 \%)\end{array}$ \\
\hline $\begin{array}{l}\text { Staphylococcus aureus } \\
\text { Streptococcus agalactiae }\end{array}$ & $\begin{array}{c}7 \\
(12.96 \%)\end{array}$ & $\begin{array}{c}3 \\
(12.00 \%)\end{array}$ & $\begin{array}{c}35 \\
(22.43 \%)\end{array}$ & $\begin{array}{c}8 \\
(10.96 \%)\end{array}$ \\
\hline $\begin{array}{l}\text { Staphylococcus aureus } \\
\text { Mycoplasma species }\end{array}$ & $\begin{array}{c}5 \\
(9.26 \%) \\
\end{array}$ & -- & $\begin{array}{c}3 \\
(1.92 \%) \\
\end{array}$ & -- \\
\hline Streptococcus agalactiae & $\begin{array}{c}9 \\
(16.67 \%)\end{array}$ & $\begin{array}{c}5 \\
(20.00 \%)\end{array}$ & $\begin{array}{c}56 \\
(35.90 \%)\end{array}$ & $\begin{array}{c}21 \\
(28.77 \%)\end{array}$ \\
\hline Mycoplasma species & $\begin{array}{c}8 \\
(14.81 \%)\end{array}$ & -- & $\begin{array}{c}4 \\
(2.56 \%)\end{array}$ & -- \\
\hline Escherichia coli & $\begin{array}{c}7 \\
(12.96 \%)\end{array}$ & $\begin{array}{c}3 \\
(12.00 \%)\end{array}$ & -- & -- \\
\hline Archanobacterium pyogens & $\begin{array}{c}5 \\
(9.26 \%)\end{array}$ & $\begin{array}{c}2 \\
(8.00 \%)\end{array}$ & -- & -- \\
\hline $\begin{array}{l}\text { Escherichia coli } \\
\text { Unidentified Gram's } \\
\text { negative }\end{array}$ & -- & $\begin{array}{c}1 \\
(4.00 \%)\end{array}$ & -- & $\begin{array}{c}5 \\
(6.85 \%)\end{array}$ \\
\hline
\end{tabular}

*: The bacteriological examinations of the collected samples focused on the common mastitis pathogens.

\#: The number between parentheses is the percentage of infection.

N.B: Corynebacterium bovis were frequently isolated from the majority of the examined samples.

Table 3: Microbial isolates* of the incurable mastitis cases:

\begin{tabular}{|l|c|c|}
\hline \multirow{2}{*}{$\begin{array}{c}\text { Isolated } \\
\text { Microorganisms }\end{array}$} & \multicolumn{2}{|c|}{ Incurable mastitis cases } \\
\cline { 2 - 3 } & $\begin{array}{c}\text { Cows } \\
(\mathrm{n}=21)\end{array}$ & $\begin{array}{c}\text { Buffaloes } \\
(\mathrm{n}=11)\end{array}$ \\
\hline Staphylococcus aureus & 9 & 8 \\
$(36.00 \%)$ & $(72.73 \%)$ \\
\hline $\begin{array}{l}\text { Staphylococcus aureus } \\
\text { Mycoplasma species }\end{array}$ & 3 & -- \\
\hline Mycoplasma species & $(12.00 \%)$ & -- \\
\hline Escherichia coli & 5 & 1 \\
& $(20.00 \%)$ & $(9.09 \%)$ \\
\hline $\begin{array}{l}\text { Archanobacterium } \\
\text { pyogens }\end{array}$ & 3 & 2 \\
& $(12.00 \%)$ & $(18.18 \%)$ \\
\hline
\end{tabular}


Table 4: Biochemical characterizations of the isolated Mycoplasma strains.

\begin{tabular}{|c|l|l|l|l|l|l|l|l|l|}
\hline $\begin{array}{c}\text { Tested } \\
\text { strains }\end{array}$ & \multicolumn{2}{|c|}{ DS } & \multicolumn{2}{c|}{ GF } & \multicolumn{2}{c|}{ AH } & \multicolumn{2}{c|}{ F\&S } & \multirow{2}{*}{ Suspected } \\
\hline \multirow{5}{*}{$51^{*}$} & $(+)$ & $(-)$ & $(+)$ & $(-)$ & $(+)$ & $(-)$ & $(+)$ & $(-)$ & Mycoplasma/Acholeplasma \\
\cline { 2 - 9 } & & $\begin{array}{l}23^{*} \\
*\end{array}$ & -- & -- & -- & -- & -- & -- & Acheloplasma species \\
\cline { 2 - 9 } & 8 & & & 8 & 8 & & & 8 & Mycoplasma arginini \\
\cline { 2 - 8 } & 20 & & & 20 & & 20 & 20 & & $\begin{array}{l}\text { Mycoplasma bovis } \\
\text { and/or } \\
\text { Mycoplasma bovigenitalium }\end{array}$ \\
\hline
\end{tabular}

DS: Digitonin sensitivity test

AH: Arginin hydrolysis test

--: Not performed

(+): Positive

*: Fifty-one strains were isolated from 28 cases of the examined dairy cows.

**: The digitonin insensitive isolates were encountered as Acholeplasma species.

Contrariwise, the sensitive strains were encountered as Mycoplasma species.

\section{DISCUSSION}

Mastitis continuously incriminated as a major enemy facing the dairy industries causing considerable level of economic losses. Results of the present work refers to the high prevalence (\% affected) of clinical $(9.56 \%)$ and subclinical mastitis $(27.61 \%)$ of the examined dairy Friesian cows. This high proportion of mastitis (clinical plus subclinical form, $37.17 \%$ ) may form a crucial risk factor for daily losses of milk production of the examined farms; decrease the daily revenue. Similarly, the prevalence of clinical and subclinical mastitis of the examined buffaloes was $6.00 \%$ and $17.50 \%$, respectively. This also reveals that $23.50 \%$ of the examined animals were positive to mastitis. The high level of mastitis in the investigated farms attributes to several causes illustrated by Edmonson and Bramely, (2004), Unhygienic sanitary measures during milking and lake and/or defects of pre- and postmilking precautions may play a stupendous role.

Statistically, CHI square analyses referred to the high susceptibility rate of dairy Friesian cows to clinical (significant increase, $\mathrm{P}<0.05$ ) and subclinical (highly significant increase, $\mathrm{P}<0.01$ ) mastitis than dairy buffaloes. This may ascribes to sundry reason including the long lactation period of cows and amount of daily yield per day. However, the natural resistance of buffaloes may play a pivotal role in such statistically significance difference. 
From etiological point of view, the current bacteriological examinations of the clinically and subclinically mastitis cases of the examined dairy cows and buffaloes concluded that Staphylococcus aureus either alone or associated with other pathogen is the predominant etiologic agent responsible for mastitis of large dairy ruminants. The frequent isolation of Staphylococcus aureus from clinical and subclinical mastitis of both dairy cows and buffaloes ranged from $37.88 \%$ to $58.02 \%$ referring to the notorious role of this pathogen in mastitis. Similar conclusion was reported by Tollersrud et al. (2006); Ali et al. (2008) and Zaitoun (2008). The later author carried out a wide crosssectional survey on mastitis of dairy buffaloes $(n=1250$, private cases) located in different areas using conventional cultural procedures for detection of mastitis pathogens. Results of this study frequently incriminated Staphylococcus aureus as a notoriousness pathogen of mastitis.

Regarding Mycoplasma infections, the current work indicates that Mycoplasma infections occupied the third grade $(19.70 \%)$ of the isolated contagious mastitis pathogens of clinical mastitis cases beyond Staphylococcus aureus $(37.88 \%)$ and Streptococcus agalactiae $(24.24 \%)$ of the examined dairy Friesian farms, but occupied the second grade $(28.57 \%)$ of the isolated mastitis pathogens from the incurable mastitis of dairy cows. Such results may refer to the significance role of Mycoplasma as pathogen of mastitis in dairy farms. On the other hand, the frequent isolation of Mycoplasma in particular Mycoplasma bovis in association with Staphylococcus aureus may refer to synergistic situation between these microorganisms.

In the current study, Mycoplasma could not be isolated from clinical and subclinical mastitis as well as from the incurable cases of the examined dairy buffaloes on four small-scale farms. This result may coincides with the published results by Eissa (1986), Zaitoun (1990) and Zaitoun et al. (1991) who suggested that buffaloes were relatively unsusceptible or less susceptible to Mycoplasma mastitis (the infection rate ranged from $0 \%$ to $2.04 \%$ ) in comparison with the dairy Friesian cows where the infection rate ranged from $17.75 \%$ to $58.33 \%$. Conversely, the offered results of El-Shabiny and Abo-El-Makarrem (1994) indicated that buffaloes were highly susceptible to Mycoplasma mastitis caused by various types of Mycoplasma; Mycoplasma bovis, Mycoplasma bovigenitalium and Mycoplasma bovirhinus, and the infection rate by using immunobinding assay reached $25 \%$ of the examined cases $(n=40)$ showed clinical mastitis at Beni-Suef 
Governorate, Upper Egypt. Such difference may ascribe to the high sensitivity of immunobinding assay than the conventional culturing procedures for detection of Mycoplasma. On the other side, it is probable that Mycoplasma mastitis appears to be more spread in Upper Egypt. However, severe outbreaks of mastitis due to Mycoplasma infection in pure form or mixed with other pathogens in Fresian farms at Kaluobia Governorate were reported (El-Ebeedy et al., 1985 and Eissa, 1986). Consequently, a recent survey on Mycoplasma mastitis of dairy cows and buffaloes in Upper Egypt by using modern technique is suggested.

The current work indicated that the majority of the isolated Staphylococcus aureus was sensitive to penicillin and its analogous, and all strains were enrofloxacin sensitive. Consequently, in-vivo therapy can be performing by these drugs. However, treatment of staphylococcal mastitis during lactation is usually unsuccessful (Watts, 1990)

From sanitary precautions point of view, Pugliese et al. (1994) indicated that Mycoplasma isolated from mastitis cases was in-vitro sensitive to different members of antibiotics that acting on the internal structures of cells such as quinolone groups particularly enrofloxacin. However, therapeutic field trials of Mycoplasma mastitis in both cows and buffaloes have a little value and the most infected udders may encountered on farms as incurable cases (Zaitoun 1991 and Zaitoun et al., 1991). Moreover, Gonzalez and Wilson (2003) corroborated that there was no efficient treatment for Mycoplasma mastitis in dairy cows and the infected animals should segregated and did not return to the dairy herd even after apparent recovery. Consequently, the culturally and/or molecularly (PCR) positive animal with Mycoplasma mastitis should culled out the dairy herd as early to avoid lateral and vertical transmission according to the results of the experimental work of Pfutzner and Schimmel (1985). They concluded that Mycoplasma bovis was transmitted vertically from the infected udder of the pregnant cows to their fetuses and after parturitions, the neonates of the experimentally infected cows were still carried Mycoplasma infection in their respiratory systems in which it remains viable and infective up to the sexual maturity. Furthermore, Mycoplasma bovis was also incriminated as a principal pathogenic agent responsible for severe fatal pneumonia and arthritis in calves in association with unrecoverable mastitis in adult cows on several dairy farms (Byrne et al., 1998 and Byrne et al., 2001).

In conclusion, the current work reveals that the prevalence of mastitis in small-scale dairy farms is at risk due to Staphylococcus 
aureus and Mycoplasma, which occupied a considerable level of contagious mastitis pathogen. Culturing detection of Mycoplasma in milk is straightforward but is often problematic because of nonmycoplasmal bacterial growth, in contrast to PCR, which is a useful detecting tool for Mycoplasma bovis, particularly in early stages of infection to lowering the overall impact on the herd. However, PCR is practically still a precious detecting assay in our field. The culturally and/or molecularly (PCR) positive cases of Mycoplasma mastitis, in particular Mycoplasma bovis mastitis, should culled as early out the dairy herd to avoid the probabilities of horizontal transmission to neighboring animals, and of vertical transmissions to the neonates and the calves. In the infected farms, Mycoplasmal examination should regularly carryout in paralleling with conventional detection of mastitis until elimination.

\section{REFERENCES}

Ahmed, A.A. and Sabry, M.Z. (1989): Studies on economic losses of mycoplasmal mastitis in a Friesian dairy herd in Egypt. J. Egypt. Vet. Med. Assoc., 49, 1 - 2, 281 - 297.

Ali, L.; Muhammed, G.; Arshad, M.; Saqib, M. and Hassan, I.J. (2008):

Bacteriology of mastitis buffaloes in Tehsil Samundri of

District Faisalabad, Pakistan. Pakistan Vet. J., 28, 1, 31-33.

Byrne, W.J.; Ball, H.J.; McCormack, R. and Brice, N. (1998):

Elimination of Mycoplasma bovis mastitis from an Irish herd.

Vet. Rec. 142, 19, 516 - 517.

Byrne, W.J.; McCormack, R.; Brice, N.; Egan, J.; Markey, B. and Ball, H.J. (2001): Isolation of Mycoplasma bovis from bovine clinical samples in the Republic of Ireland. Vet. Rec. 148, 11, $331-333$.

Edmonson, P.W. and Bramely, A.J. (2004): Mastitis: In Bovine Medicine Diseases and Husbandry of Cattle. The $2^{\text {nd }}$ Ed. Edited by Andrews, A. H. (Chief Editor); Blowey, R. W.; Boyed, H. and Eddy, R.G. (contributors) Blackwell Science. Pages $226-336$.

Eissa, S.I. (1986): Some studies on mycoplasma mastitis of cattle and buffaloes in Egypt. Ph. D. Thesis Faculty of Vet. Med., Alexandria Univ., Egypt. 
El-Ebeedy, A.A.; Gad, A.S.; Rashwan, Amal; Mostafa, A.; El-Ahl, S.S.; Esmail, S. and Allam, N.M. (1985): Isolation of Mycoplasma bovis from an outbreak of bovine mastitis in Egypt. J. Egypt. Vet. Med. Assoc., 45, 1, 247 - 253.

El-Shabiny, Laila and Abou-El-Makarem, Manal (1994): Rapid diagnosis of mycoplasma infection in buffaloes using immunobinding assay. Vet. Med. J., Giza, 42, 2, 47 - 49.

Gonzalez, R.N. and Wilson, D.J. (2003): Mycoplasma mastitis in dairy herds. Vet. Clin. North Am. Food Animal Pract., 19, 1, 199 221.

Kobayashi, H.; Hirose, K.; Worarach, A.; Paugtes, P.; Ito, N.; Morozumi, T. and Yamamoto, K (1998): In vitro amplification of the 16S rRNA Genes from Mycoplasma bovirhinis, Mycoplasma alkalescens and Mycoplasma bovigenitalium by PCR. J. Vet. Med. Sci., 60, 12, 1299 - 1303.

Lewis, A.E. (1966): The CHI - Square distribution. In Biostatistics. Reinhold Publishing Corporation, New York. Pages 110 - 124.

Lunini, M.; Gualdi, V.; Maietti, I.; Vezzosi, F.; La-Malfa, C.; Radaelli, E.; Soriolo, A.; Albeton, A.; Fin, M. and Rodeghiero, M. (2006): Mycoplasma bovis in fattening cattle with respiratory disease. Large Animals Review 6, $11-15$.

Nicholas, R.A.J.; Ayling, R.D. and McAuliffe, L. (2008): Mycoplasma Diseases in Ruminants. First Edition, Veterinary Laboratory Agency. CAB International

Nicholas, R.; Ayling, R. and McAuliffe, L. (2009): Vaccines for Mycoplasma diseases in animals and man. J. Comp. Pathol., $140,58-96$.

Ortez, J.H. (2005): Disc diffusion testing. In Manual of Antimicrobial Susceptibility Testing. Coyle, M. B. (Coordinating Editor), First Ed, American Society for Microbiology, Pages 39 - 52.

Palanivel, K.M.; Prabakar, T.G.; Selvasubramanian, S. and Vijayalingam, T.A. (2008): Epidemiology of bovine mastitis in and around Chennai. Indian Journal of Field Veterinarians. $3,3,24-27$.

Pfutzner, H. and Schimmel, D. (1985): Mycoplasma (M) bovis Nachweise bei Nachkommen von an $M$. bovis-Mastitis erkrankten kuhen und ihre epizootiologische Bedeutunge. Zentralblatt für Veterinärmedizin, B, 32, 4, 265 - 279. 
Pugliese, A.; Niutta, P.P.; Pizzimenti, P.C.; Naccari, F.; Giudice, E.; Pagano, A. and Catarsini, O. (1994): Use of enrofloxacin against mastitis in sheep and goats. Administration by supramammary injection. Obiettivi e Documenti Veterinari. 15, $10,47-49$.

Radaelli, E.; Luini, M.; Loria, G.R.; Nicholas, R.A.J. and Scanziani, E. (2008): Bacteriological, serological, pathological and immunohistochemical studies of Mycoplasma bovis respiratory infection in veal calves and adult cattle at slaughter. Res. Vet. Sci., 25, $282-290$.

Reddy, P.; Qi, C.; Zembower, T.; Noskin, G.A. and Bolon, M. (2007): Postpartum mastitis and community-acquired methicillinresistant Staphylococcus aureus. Emerg. Infect. Dis., 13 2, 298-301.

Riekerink, G.M.; Barkema, H.W.; Veenstra, S.; Poole, D.E.; Dingwell, R.T. and Keefe, G.P. (2006): Prevalence of contagious mastitis pathogens in bulk tank milk in Prince Edward Island. Can. Vet. J., 47, 567-572.

Rodwell, A.W. and Whitecomb, R.F. (1983): Methods for direct and indirect measurments of Mycoplasma growth. .In Methods in Mycoplasmology. V: I Academic Press. First Ed. Edited by Razin, S and Tully, J.G., Pages $185-196$.

Stalheim, O.H.V. (1990): Mycoplasmas of Animals. In Diagnostic Procedure of Veterinary Bacteriology and Mycology. The $5^{\text {th }}$ Ed., Edited by Carter, G.R. and Cole, Jr. J. R. Published by Charles $\mathrm{C}$ Thomas Publisher, Springfield Illinois, USA. Pages $343-370$.

Tollersrud, T.; Kampen, A.H. and Kenny, K. (2006): Staphylococcus aureus entrotoxin D is secreted in milk and stimulates specific antibody responses in cows in the course of experimental intramammary infection. Infection and Immunity, 74, 6,

Watts, J.L. (1990): Bovine Mastitis. In Diagnostic Procedure of Veterinary Bacteriology and Mycology. The $5^{\text {th }}$ Ed., Edited by Carter, G.R. and Cole, Jr. J. R. Published by Charles C Thomas Publisher, Springfield Illinois, USA. Pages $469-478$.

Zaitoun, A.M.A. (1990): Role of some mycoplasma species in bovine mastitis. Ph D Thesis, Infectious Diseases, Faculty of Vet. Med., Assiut University, Assiut, Egypt. 
Zaitoun, A.M.A. (1991): Investigations on bovine mycoplasma mastitis in Upper Egypt. Proceeding. The first Scientific Congress of Cattle Diseases. Egyptian Society for Cattle Diseases. AssiutEgypt, December 1 - 3, 108 - 118.

Zaitoun, A.M.A. (2008): Clinical mastitis caused by Staphylococcus aureus in dairy buffaloes. Assiut Vet Med., 54, 119, $289-310$.

Zaitoun, A.M.A.; El-Allawy, T.A.; Abdallah, I.S.; El-Ebeedy, A.A.; Eissa, S.I. and El-Shabiny, Laila. (1991): Incidence of mycoplasma infection in mastitic cows and buffaloes in Upper Egypt. Assiut Vet. Med. J. 25, 50, $108-114$. 